\title{
China's Dilemma in Human Rights: Through the Perspective of Critiques Abroad and China's Response
}

\author{
Bo $\mathrm{CHEN}^{1,2}$ \\ ${ }^{1}$ College of Postgraduate Education, East China University of Political Science and Law, Shanghai, China \\ ${ }^{2}$ University of Hong Kong, Hong Kong SAR, China \\ Correspondence: Bo CHEN, College of Postgraduate Education, East China University of Political Science and \\ Law, Shanghai, China. Tel: 86-1-358-587-6017. E-mail: chenbolaw@hotmail.com
}

Received: May 22, 2012 Accepted: June 3, 2012 Online Published: August 21, 2012

doi:10.5539/jpl.v5n3p25 URL: http://dx.doi.org/10.5539/jpl.v5n3p25

\begin{abstract}
In the previous years, China has been trying to adopt the value of human rights in its legislation, justice and administration. However, China's efforts were not acknowledged by the foreign countries and non-governmental organizations for the exposed severe human rights situation.

The events in China always draw the eyes of other countries and the critiques and pressure from western world make China respond and transform itself. The critiques are mainly on the one-child policy, Tibetan problem and the rule of law in China. To different problems, China also responds in different ways.
\end{abstract}

Keywords: one-child policy, Tibet, rule of law, diplomacy, NGO, human rights reports

\section{Introduction}

In the previous years, China has been trying to adopt the value of human rights in its legislation, justice and administration. However, China's efforts were not acknowledged by the foreign countries and non-governmental organizations. Especially the last 13 years witnessed no absorbing of International Convention on Civil and Political Rights (ICCPR) into internal law after China signed to participate it in 1998, China's has been suspected to fulfill its expectation to enter the World Trade Organization (WTO), which requires an internal legal system administered in a "uniform, impartial, and reasonable manner".

\section{The Darkest Days of China's Human Rights}

The critiques towards China's situation of human rights have never ceased since Tiananmen incident although it is not the most severe disaster of human rights in China. The darkest days of China's human rights were the Cultural Revolution from 1966 to 1976. "Many reasons have been offered for Mao's mobilization and unleashing of forces that probably consumed 2,000,000 lives in country-wide terror, mass murder, and battles." (Rummel, 2007)

However, the Cultural Revolution was not noticed by the foreign countries at that time. On one hand, in the earlier years, China's diplomacy policy was to be together the socialism community and was hostile to the western countries. China was almost isolated from the countries of capitalism and the international communication was mainly with the socialism community. Therefore, the close observation towards China's human rights was impossible. On the other hand, although the United Nations promulgated the Universal Declarations on Human Rights (UNDHR) in 1948, it was not seriously enforced after the cold war. "The $U N$ $D H R$ was given a more practical, legally specific manifestation in 1976 when the International Covenant on Civil and Political rights (ICCPR) and International Covenant on Economic, Social and Cultural Rights (ICESC) officially came into effect after a decade of ratification.” (Deng, 2008)

In the end of 1970s, the disastrous Cultural Revolution terminated, Chinese people including the top officials began to concentrate on the economic development. In 1978, the open and reform policy was implemented and the cooperation with western countries was intensified. Thereafter, the closest scrutiny to China became possible for western countries.

\section{The Tiananmen Incident}

The crisis in China's human rights occurred in 1989 after the astonishing Tiananmen incident. "On the night of 
June 3-4, 1989, Deng Xiaoping and his government allies deployed military force to clear Tiananmen Square and end demonstrations across China. The ensuing chaos and bloodshed not only shook the Chinese people, but also horrified the world community." (Tucker, 2001)

In the aftermath, various nations applied sanctions toward China. Tourism, trade and investment slumped, and human rights became central to political intercourse with Beijing. Facing with the pressure from western countries, Chinese authorities subsequently announced there was "no one died" during the crackdown. (Tucker, 2001) For instance, after the Tiananmen incident "There were demands in the United states for stronger action to punish the 'Butchers of Beijing'. The administration canceled a series of high visits. Congressional declarations from members across the political spectrum denounced the Chinese government and many legislators called for even harsher measures." (Cohen, 2000)

After the Tiananmen incident, the economic reform deepened in China, the cooperation between China and western countries is of great significance to the economic development in China. For the disparity of value between CCP and west, the China, the western countries were hesitated to build healthy bilateral relations with China.

Since that time, China became responsive to the critiques. "To lessen censure abroad, China has been both responsive and resistant to international pressures, but the slow pace of political liberalizations at home has limited compliance. The country has sought to simultaneously oppose the use of human rights to justify discriminatory treatments of illiberal states and redefine the international standard itself." (Deng, 2008)

In the past two decades, the critiques as well as the response in human rights of China have never ceased. For instance, Human Rights in China (HRIC), founded by Chinese students and scholars in March 1989, is an international, Chinese, non-governmental organization with a mission to promote international human rights and advance the institutional protection of these rights in the People's Republic of China. Apart from that, the NGOs such as human rights watch and Amnesty international also began to comment the incidents in China and sometimes also publish their comments in a single case of China. The government of foreign countries also put a finger in China's human rights; US government has published Country Reports on Human Rights Practice.

Chinese government also responds to the critiques through its organizations. Chinese government publishes the human rights report of US as response to the critiques from US. The in the press conferences, the spoke persons became active towards the comments and pressure from western countries.

There are many aspects that China criticized by the foreign countries and NGOs. The main critiques are concerned with one-child policy, the Tibetan problem, defects of the rule of law as well as the political rights and civil rights.

\section{The Critiques on One-child Policy}

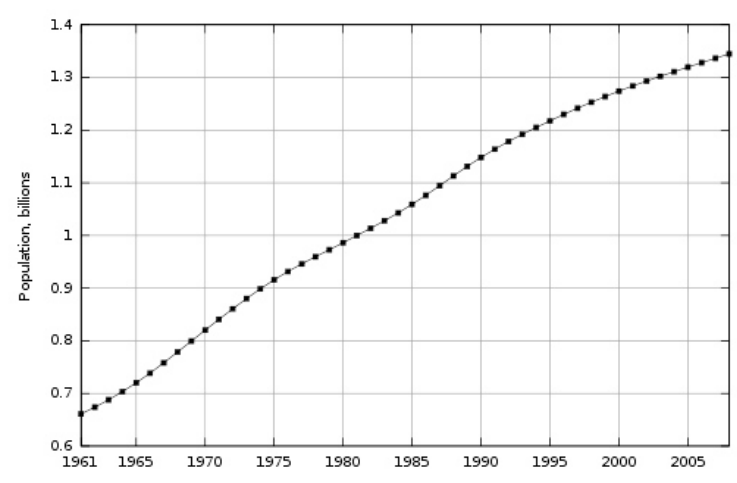

Figure 1. China Demography (Note 1)

For the policy of Mao's era was encouraging the mothers to have more Children, as well as the development of health care, the population almost doubled during his period. The population of China in 1949 was 541,670,000 which increased to $1,000,720,000$. (Statistics Year Book of China, 1984) The high population increase gave China a huge pressure in 1970s, consequence of the limited resource and the increasing population began to emerge. To alleviate social economic and environmental problems in China, Chinese government turned to the birth controlling for help. The Birth Control Law of PRC restricts married, urban couples to having only one child, 
and rural couples to having 2 children if the first is female, while ethnic minorities are not restricted.

Unlike other nations of world, China is the only country in the world using legislation and administration power to control the birth rate. Especially in the religious countries, giving birth to Children has become a divine right.

The critiques on one-child policy are based on abandoned or orphaned children and adoption, infanticide, gender-based birth rate disparity in the implementation of one-child policy.

\subsection{Abortion, Abandoned or Orphaned Children and Adoption}

In 2006, a documentary called China's Lost Girls made the world paid attention to China's Children adoption. Unfortunately, the "orphaned" children were all girls and no boys were abandoned in China. Some of the abandoned girls were adopted by foreign families. After further analysis, people found the above situation was caused by the strict enforcement of the one-child policy. In the last 30 decades, Chinese people have invented various methods to avoid it. The methods include sex-selective abortion, abandoning, even trade of boys.

According to the traditional minds of Chinese society, boys are more "valuable" than girls for boys are deemed be able to continue the blood of families. However, one-child policy does not allow the parents to have another child, some couples chose to abandoning the girls. However, this is not the only method to avoid the law.

The more popular method is abortion; the couples go to hospitals to examine the gender of fetus and some of them choose to abort if the fetus is female. "Two researchers say comprehensive new data shows that traditional family patterns in China, combined with tough population-control measures, have resulted in 'female infanticide on a grand scale' - close to 800,000 baby girls abandoned or killed in a single region between 1971-80 alone." (Sarah Lubman)

\subsection{The Problems in the Process of the Enforcement of One-child Policy}

Another problem of China's one-child policy is the implementation process; "Some western commentary criticize the one Child policy because of the ideological authoritarianism that is in the back ground of enforcement procedures." (Johnny Shaw, 2002)

Another defect is the illegal conducts by governmental officials when implementing the one-child policy; some illegal methods have been used. The illegal imprisonment and seizure of property as fines are usual events in China. Sometimes, the governmental officials resort to violence to enforce the law. The abortion or sterilization under coercion is two methods for governmental officials.

Some scandals illustrate the local governments took the orphan-adoption to foreigners as an approach to increase income. It was reported that the government bodies in Hunan province put the children out of the plan in orphanage to collect fines from the parents. If the parents could not pay the fines, their children may be adopted by foreigners for they can pay a large sum of money around 3000 dollars. "Many parents and grandparents in this mountainous region of terraced rice and sweet potato fields have long known to grab their babies and find the nearest hiding place whenever family planning officials show up. Too many infants, they say, have been snatched by officials, never to be seen again." (Sharon Lafraniere, 2011)

And the Birth control law has also been violated by the governmental officials. "National law prohibits the use of physical coercion to compel persons to submit to abortion or sterilization. However, intense pressure to meet birth limitation targets set by government regulations resulted in instances of local family-planning officials using physical coercion to meet government goals. Such practices included the mandatory use of birth control and the abortion of unauthorized pregnancies. In the case of families that already had two children, one parent was often pressured to undergo sterilization." (2010 Country Reports on Human Rights Practice by US)

"A U.S.-based human rights organization reported that in August, the one-month-old daughter of a mother in Changfeng County, Anhui Province was detained by local family-planning officials until the woman signed a document consenting to a sterilization procedure." (2010 Country Reports on Human Rights Practice by US)

\subsection{China's Response to the Critiques in One-child Policy}

Although the problems have been detected, the Chinese government reaffirmed the one-child policy in the $12^{\text {th }}$ five year plan period. It is reported that the policy may be altered in 2020, that means the opportunity to have 2 children may be possible in the future. "It is most likely that China's official population policy will remain in effect over the next few years, while local modification on family planning regulation can be expected. "Two children per family' will finally replace the present family planning policy." (Takayama \& Werding, 2010)

\subsection{In Order to Develop the Economy}

The one-child policy is one reason that China's development can rank $2^{\text {nd }}$ in the world. The same conclusion is 
also reached by western scholars. The large number of working population and smaller number of children give the society less burden on the resource. Because, the revenue collected by the government is higher while the investment on education, health care, etc. for children are relatively lower.

\subsection{China is Seeking to Improve the Policy}

The Birth Control law was not enforced until 2002, in other words, from 1978 to 2002, the implementation of one-child policy did not regulated by any law. The illegal methods in the enforcement of one-child policy are partially caused by the lack of law.

However, the problems of the one-child policy have also emmerged. One problem is the unbalance of gender; the Chinese Academy of Social Sciences estimated that by 2020, there could be as many as 24 million more men than women of marriageable age (aged 19-45) in China. In September Vice Premier Li Keqiang announced that the government would "launch measures to narrow the widening ratio of men and women."

\subsection{The Aging Problem}

"The total elderly population (aged over 65 ) increased up to 113 billion by $2009,8.5$ percent of the overall population; the number is expected to increase continuously and to reach its peak, at three times its current size, in the middle of twenty-first century." (Takayama \& Werding, 2010) The coming aging crisis is quite obvious that China's working population will decline significantly and the burden of pension will increase.

\section{The Tibetan Problem}

\subsection{The Critiques}

Since the occupation of Tibet by People Liberal Army in 1951, the potential of unrest was planted. In 1959, Dalai Lama fled to India with 80,000 followers. (Note 2) In the 1990s, China was criticized by Amnesty international for its violence in Tibet. "In early March 1989 martial law was declared in Lhasa and remained in force for more than a year. It was imposed during large-scale protests in favor of independence which included violence confrontations with security forces." (Amnesty international, 1996)

The latest unrest happened in 2008 which once again drew the eyes of world. After the series of riots, protests, and demonstrations, Chinese government controlled Lahsa. However, the riots were not rested, at the same time but also in response, protests mostly supporting the Tibetans erupted in cities in North America and Europe. 18 Chinese embassies and consulates were attacked. (Note 3)

Chinese government also received world-wide critiques. The word "Tibet" was repeated 209 times in 2008 Human Rights Watch Report which thoroughly commented Lahsa riots. Most of the comments are malicious to China. "The government's human rights record remained poor and worsened in some areas. During the year the government increased its severe cultural and religious repression of ethnic minorities in Tibetan areas and the Xinjiang Uighur Autonomous Region (XUAR), increased detention and harassment of dissidents and petitioners, and maintained tight controls on freedom of speech and the Internet. Abuses peaked around high-profile events, such as the Olympics and the unrest in Tibet." (2008 US Annual Country Human Rights Report)

The problem of Tibet has been a key element either in or out of China. Dalai Lama, the former head of state for the Central Tibetan Administration, who won the Nobel prize under the state of exile. Dalai Lama's receptions and honor by foreign politicians, organizations or royal families always trigger the tensions between China and foreign countries.

4 years passed since the riots of 2008, although the riots in Tibet had been cracked down, the issue of Tibet is also an important part in the eyes of foreign countries. "The Chinese government gave no indication it would accommodate the aspirations of Tibetan people for greater autonomy, even within the narrow confines of the country's autonomy law on ethnic minorities' areas. There were no mass arrests in 2010 of the kind that followed the spring 2008 protests, but the government maintains a heavy security presence across the Tibetan plateau and continues to sharply curtail outside access to most Tibetan areas." (2011 Annual Human Rights Watch Report)

The main critiques on the problem of Tibet are: the unlawful deprive of life, Civil Liberties, and others. But the root reason of the infringement of the breach of rights is Tibetan independence. The critiques also noticed that which is deemed as the core interest of China. In the 2011 human rights report of China, the phrase "Tibetan independence" was repeatedly used to illustrate the methods China used to prevent Tibetan independence.

\subsection{China's Response to the Problem of Tibet}

Unlike the critiques on other problems, the Tibet has been deemed as the core interest of China, which involves territorial integrity. China also sternly responds to any critiques on that. 


\subsection{The Historical Relationship with Tibet}

Some western countries have been alleging the People's Liberal Army's entering Tibet is invasion in 1951. Responding to the western critiques on the "occupation or invasion" to Tibet in 1951, China stated that PLA's entering to Tibet was according to a document 17 points agreement, thus, it was to fulfill the duty and obligation of the agreement. Therefore, the western critics mistakenly the distinctions of entering with consent and entering without consent. (Xinhua News Agency, 2011)

This fact has been proved by the inconsistent statements in some books. Such as "In sum, prior to the 1950 Chinese invasion, Tibet had achieved de facto independence and all of the requirements of de jure independence except formal international recognition." (International Commission of Jurists, 1997) In the same book there is another statement "After Tibetan acceptance of the 17-point Agreement, the PLA occupied Lhasa and central Tibet." (International Commission of Jurists, 1997)

\subsection{The Misleading Reports of Western Media}

In the previous years, the western media occasionally used mistaken or misleading information to illustrate the situation of Tibet. In the riots of 2008, the gangsters killed over 140 Lahsa citizens and tourists and many houses were burned. However, some western media had never mentioned the above facts in their reports. Apart from that, they also used wrong pictures in their reports, one of the picture appeared in a report was proved downloaded from a website many years ago. And another picture used by CNN was found being processed in advance.

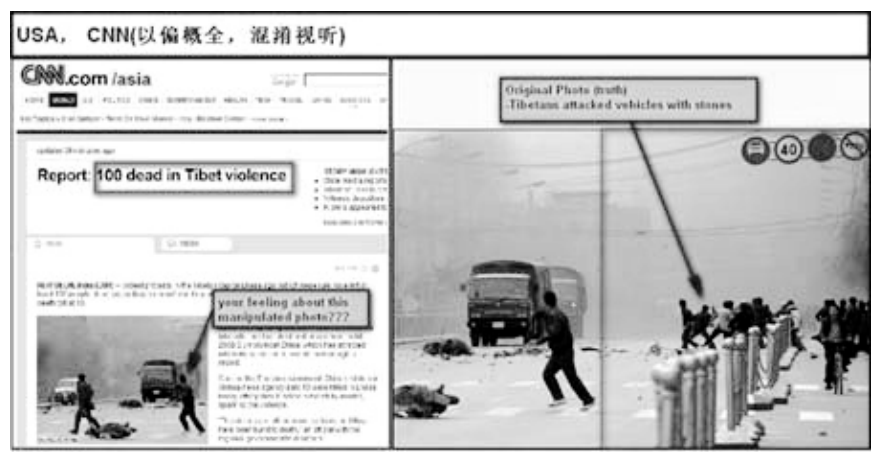

Figure 2. Example of this misleading report of CNN

Description: The left picture was the picture posted on CNN's web site, while the right is the original picture showing Gangsters were throwing stone to the Lorry. (Note 4)

The authors in their books do not give any ink to the death of plain people killed by gangsters. For instance, chapter 15 of the book Freeing Tibet: 50 Years of struggle, Resilience, is talking about the "uprising of 2008 " but does not mention the real situation. (Note 5)

\subsection{Responding with Diplomatic Pressure}

China also uses the diplomatic power to protest the events concerned with the interests of China. For instance, in 2007, Bush and Congress Honored Dalai Lama as a protest over the award, China pulled out of a multiparty meeting this month to discuss Iran. (Knowlton, 2007)

\subsection{The Principle of No Interference of Internal Affairs}

China has been accusing the interference of Chinese affairs and the intention of foreign countries. The human rights and other affairs are regarded as a tool for their own interests. "The (US) congress tabled many negative bills on Tibet, Taiwan, the Beijing Olympic Games and economic matters and Trade." "The Chinese side made stern representations on the erroneous remarks and actions of the US side and made clear its staunch position of opposing the US side's attempt to interfere China's internal affairs on issues of human rights, religion and Dalai" (Ministry of Foreign Affairs of PRC, 2009).

\section{The Problems in China's Rule of Law}

The situation of China's rule of law is far from perfect. There are many defectives in almost every aspects of it. And it is also criticized by the western world. The serious and continuous violation of basic human rights in 
justice by the officials has hindered the construction of the society of rule of law. For the protection of human rights within a society should be the primary concern of legal and judicial system. The current Chinese laws include many provisions that express respect for human rights of citizens, but how to guarantee the application of these provisions is still a thorny problem.

Although the scholars define "the rule of law" in varied ways, they must agree that "the rule of law" should initially be distinguished from "rule of men". More positively, scholars in both China and the West and in both the past and the present tend to agree that the criteria of rule of law requires the following elements: transcendent values, natural law, rationality, publicity, fixity, consistency, universality, constitutionality, separation of powers, an independent judiciary, professional lawyers, human rights, and broad political participation. However, almost every aspect of the above aspects was breached by Chinese government.

\subsection{The Ineffective Human Rights Protection in Criminal Justice}

The problem of torture in China has been accused by the western world for many years. "Torture is inflicted on political and common criminal prisoners alike. Anyone is at risk if they cross the authorities. People who were not suspected of any crime have been tortured because they became involved in disputes with police and other official, or because they attempted to defend their rights." (Amnesty international, 1996)

The modern criminal justice invents many instruments to guarantee the justice and human rights in criminal cases. The instruments include the independent judiciary, clarity of procedure as well as presumption of innocence. In accordance with Article 2 of criminal procedural law, the aim of the Criminal Procedure Law of the People's Republic of China is: to ensure accurate and timely ascertainment of facts about crimes, correct application of law, punishment of criminals and protection of the innocent against being investigated for criminal responsibility.

However, the judicial organs put the emphasis on fighting with crime while disregarding of the protection of human rights. "There was no presumption of innocence, and the criminal justice system was biased toward a presumption of guilt, especially in high-profile or politically sensitive cases." (2008 Human Rights Report: China)

The interference of CPC towards the criminal justice sometimes causes unjust. For instance, a Henan farmer, named Zhao Zuohai, was released after serving ten years for murder as "victim" turned up alive. According to the reports, this unjust case was coordinated by the local politics and law committees of CPC.

\subsection{Criminal Punishments to Human Rights Activists}

Perhaps no other issue raises greater passion in political and legal discussion about China than the question of respect for basic human rights.

According to Amnesty International, a $N G O$ specified in human rights protection, many political activists have been imprisoned. One of the imprisoned activists is Liu Xiaobo, who was awarded 2010 Nobel Peace Prize for "his long and non-violent struggle" for fundamental human rights in China. Liu was sentenced to eleven years' imprisonment and two years' deprivation of political rights on 25 December 2009. Apart from Liu Xiaobo, other activists like Ai Weiwei were also detained for criticizing CPC, but released after one month. (Amnesty International, 2011)

\subsection{Abuse the Administrative Power}

The Chinese government especially the local ones has been used to abuse powers towards the local people. These problems have also been criticized

"Despite pervasive state censorship, rights advocates helped generate public and media debate on issues including illegal detention centers for petitioners travelling to the capital to lodge grievances (known as "black jails"), abnormal deaths in custody, widespread torture to extract confessions, use of psychiatric facilities to detain dissenters, socioeconomic discrimination against ethnic minorities in Xinjiang, and endemic abuses linked to forced demolitions and eviction." (US human rights report of China, 2011)

Due to various reasons, mostly of which are relevant to politics, it is far from easy to harness the executive power. For example, these years, there are always some tragedies caused by the forced building demolition. As a matter of fact, the forced building demolition violates the Constitution and Real Right Law. However, the local governments usually use it to earn their own interests. This issue was highlighted by the case of Tang Fuzhen, a resident of Chengdu, capital of Southwest China's Sichuan province. The 47-year-old woman died in 2009 after setting herself on fire to protest the forced demolition of her former husband's house. Such tragedies also happened in Jiangsu, Jiangxi and other parts of China. Recently, another event happened in Guangdong province, 
"Villagers in Wukan have been protesting what they said was the local government's latest attempt to secretly sell off their farmland to developers. The villagers said local Communist Party officials had not consulted them on the sale and that they only learned of it after construction work began. The leader of the protest died after being detained in the prison." (Note 6) (Amnesty international, 2011)

The forced demolition is only one tip of the iceberg. The local governments have been used to the illegal measures to cope with the issues which are supposed to be solved by law. How to harness the administrative power is the most urgent problem on China's road to the society of rule of law.

\subsection{The Stringent Social Control}

The "Weiwen"(keeping stability) is one of the most important targets. It was reported that the expense of it exceeded the defense expense. People's freedom of speech, especial the journalists are continuously monitored and punished by the government. "At least 24 Chinese journalists are jailed on ambiguous charges ranging from 'inciting subversion' to 'revealing state secrets.' They include Gheyret Niyaz, a Uighur journalist and website editor, sentenced to 15 years in June for "endangering state security" related to a foreign media interview he gave after the July 2009 protests in Xinjiang." (US human rights report of China, 2011)

"The government continued to restrict the rights and freedoms of journalists, bloggers and an estimated 384 million internet users, in violation of domestic legal guarantees of freedom of press and expression. The government requires state media and internet search firms to censor references to issues ranging from the June 1989 Tiananmen massacres to details of the 2010 Nobel Peace Prize." For instance, Google renews its threat to leave China; HRW's Arvind Ganesan says there's a growing call for more American companies to take a stand against Internet censorship.

\subsection{The Response of China}

Although the critiques on China's rule of law are quite severe, most of them are true. Most of the events are firstly reported by domestic media, and then commented by foreign countries and NGOs. China keeps a responsible attitude towards the problems, because China also is aware the problems.

If the problems of the rule of law are not solved, China will eventually suffer from the results. For fearing the uprising of whole country, the government puts more attention on the economy.

\subsection{The Efforts to Promote Fair Market}

In China, the governments of all levels are trying their best to promote the local or national economy in various methods. Unfortunately, in some parts of China, the governments even have been using improper measures which infringe the interests of citizens.

As a country of market economy, the resources should be distributed by the necessity of market. However, the state-owned enterprises are always at an advantageous position. The governments use executive power to control the market to help the state-owned enterprises. Consequently, the private economies, which should be equally protected and treated, cannot enjoy the advantages. In certain industries, like gas, telecom and banking, the state owned enterprises have formed monopoly. In the long run, these phenomena may be detrimental to China's economy.

The relationship of government and its citizens is a complicated notion in society. In the vision of rule of law, within China and elsewhere, the executive power should be imposed on effective and meaningful limitations. Law must be generally applicable, no matter who is the subject. Theoretically, all kinds of powers must be restricted and operate under supervision. If the restriction and supervision become invalid, it inevitably leads to corruptions. Just as a famous saying goes, power tends to corrupts, and absolute power corrupts absolutely.

Furthermore, the executive power is supposed to be the monitor of the society. Its responsibility is to guarantee fair competition through enforcing laws, ensuring the welfare of its citizens through programs in public health, housing, pension, and employment, etc., and safeguarding the members of society from any forms of infringements. However, the status quo of the above aspects is not as perfect as expectation. There are many drawbacks on this issue.

\subsection{Promoting Sufficiency of Public Welfare}

The rapid economic progress makes China overtake Japan as world's second-biggest economy. That means the government has the capacity to realize the welfare of throughout the whole country. Most economists agree that while China as a whole is growing, the income of its citizens is not increasing correspondingly. The average Japanese person is much richer than the average Chinese person. The International Monetary Fund estimates that GDP per head of the population is almost $\$ 34,000$ in Japan, while in the People's Republic of China it is just 
over $\$ 7,500$. What's more, the Japanese people can enjoy the social welfare which is impossible in China.

The public welfare costs are unevenly distributed; to illustrate, most the rural citizens cannot enjoy the welfare provided by the government. They have to pay for the expense of health and pension by themselves. Even to the unban citizens, the amount of welfare is not adequate to maintain the basic life.

\section{References}

Amnesty International. (1996). No One is Safe: Political repression and abuse of power in the 1990s. London: Amnesty International Publications.

Amnesty International. (2011). China must end land grabs amid protests over death in custody. Retrieved November 11, 2011, from $\mathrm{http}: / / w w w . a m n e s t y . o r g / e n / n e w s / c h i n a-m u s t-e n d-l a n d-g r a b s-a m i d-p r o t e s t s-o v e r-d e a t h-c u s t o d y-2011-12-14$

Ardley, J. (2002). The Tibetan Independence movement: Political, Religious and Gandhian Perspective. London: Routledge Cuzon. http://dx.doi.org/10.4324/9780203221150

Cohen, W. I. (2000). America's response to China: A history of Sino-American Relations (4th ed). Columbia: Columbia University Press.

Deng, Y. (2008). China's Struggle for Status: The realignment of international Relations. London: Cambridge University Press. http://dx.doi.org/10.1017/CBO9780511790768

John, B. R., \& Elizabeth A. R. (2009). Freeing Tibet. American Management Association.

Knowlton, B. Bush, \& Congress Honor Dalai Lama. The New York Times. Retrieved December 11, 2011, from http://www.nytimes.com/2007/10/18/washington/18lama.html

Liao, Z. G., \& Zhang, Z. J. (1996). Thesis on Tibetology in China. Beijing: China Tibetology Publishing House.

Mattnews, R. (2008). The absolute violation: why torture should be prohibited. London: McGill-Queen's University Press.

Ministry of Foreign Affairs of PRC. (2009). China Foreign Affairs. Beijing: World Affairs Press.

Rummel, R.J. (1991). China's Bloody Century: Genocide and Mass Murder Since 1900. US: Transaction Publishers.

Sarah, Lubman. Infanticide detailed in China. Retrieved December 13, 2011, from http://www.abortiontv.com/Misc/ChinaAbortions.htm

Sharon, Lafraniere, New York Times, Officials in China Seized Infants for Black Market, Parents Say. Retrieved December 15, 2011, from http://query.nytimes.com/gst/fullpage.html?res=9D02E3DA1531F936A3575BC0A9679D8B63\&\&scp=4\& $\mathrm{sq}=$ shaoyang $\& \mathrm{st}=\mathrm{cse}$

Shaw, J. (2002). Public Administration of the One-child Policy in the People's Republic of China: Population Panacea or Ideological Mare's Nest. California: Dissertation of University of Southern California

Takayama N., \& Werding M. (2010). Fertility and Public Policy: How to reverse the Trend of Declining Birth Rates. Massachusetts: The MIT press.

Tuncker, N. B. (2001). China Confidential. New York: Columbia University Press.

XINHUA News Agency. Why Tibet is one part of China? Retrieved November 14, 2011, from http://www.chinanews.com/gn/2011/07-19/3192126.shtml

\section{Notes}

Note 1. Source: Wikipedia, website: http://en.wikipedia.org/wiki/File:ChinaDemography.svg

Note 2. International Commission of Jurists, Tibet: Human rights and the Rule of Law, 1997.

Note 3. Source: Wikipedia, website: http://en.wikipedia.org/wiki/2008_Tibetan_unrest

Note 4.4 Source: mina net, website: http://www.chinamil.com.cn/site1/2008a/2008-03/28/content_1181493.htm

Note 5. The fact can be checked in John B. Robert II, Elizabeth A. Roberts, Freeing Tibet, American Management Association, 2009.

Note 6. Amnesty international, China must end land grabs amid protests over death in custody, website: $\mathrm{http}: / /$ www.amnesty.org/en/news/china-must-end-land-grabs-amid-protests-over-death-custody-2011-12-14 